Original Research

\title{
Effort to Prevent Anaemia during Menstruation among Female Adolescent in Islamic Boarding School
}

\section{Esti Yunitasari, Praba Diyan Rachmawati and Desy Indah Nur Lestari}

\author{
Faculty of Nursing, Universitas Airlangga, East Java, Indonesia
}

\section{ABSTRACT}

Introduction: Female adolescents are generally prone to be infected by anaemia due to the growing menstruation cycle which causes the loss of bloods in significant amount every month and the needs of ferrum substance can be doubled. The aimed of the research was to analyse factors related to the effort of anaemia prevention during menstruation among female adolescents in Islamic boarding school.

Methods: This research applied correlational descriptive design through the approach of cross-sectional study. Total samples were 214 female students in 3 Islamic boarding schools with criteria of female students aged 11-20 years old and had experienced menstruation. Sample obtained by random sampling. Independent variables were knowledge, attitude, friends support, health facility, health efforts, and dependent variables was the efforts to prevention anaemia. Data obtained by questionnaire and analyzed by Spearman Rho with significance level $\alpha, 0.005$

Results: The result showed significant correlation between knowledge $(p=0.000$; $r=0.318)$. attitude $(p=0.001 ; r=0.232)$. friends support $(p=0.003 ; r=0.203)$. health facility $(p=0.000 ; r=0.260)$. and health efforts $(p=0.001 ; r=0.227)$ on prevention effort of anaemia on adolescents female menstruation in Islamic boarding school.

Conclusion: Level of knowledge, posstive attitude, friends support, health facility, and health efforts can prevent anemia during menstruation.
\end{abstract}

\section{ARTICLE HISTORY}

Received: October 04, 2018

Accepted: March 19, 2019

\section{KEYWORDS}

anaemia; knowledge; attitude friends support; health facility; health efforts

\section{CONTACT}

\section{Esti Yunitasari}

$\triangle$ esti-y@fkp.unair.ac.id

$\doteq$ Faculty of Nursing,

Universitas Airlangga East Java, Indonesia

Cite this as: Yunitasari, E., Rachmawati, P.D., \& Lestari, D. I. N. (2019). Effort to Prevent Anaemia during Menstruation among Female Adolescent in Islamic Boarding School. Jurnal Ners, 14(1), 28-32. doi:http://dx.doi.org/10.20473/jn.v14i1.9928

\section{INTRODUCTION}

Anaemia is a condition whereby the level of haemoglobin $(\mathrm{Hb})$ within blood is lower than the normal scale (World Health Organization, 2011). Diagnosis of anaemia can be upheld once the degree of haemoglobin is $<12 \mathrm{~g} / \mathrm{dl}$ on female and $<13 \mathrm{~g} / \mathrm{dl}$ on male. Anaemia needs to be overcome due to its ability to degrade body endurance, hence, sufferers of anaemia are prone to infectious disease. it can reduce physical fitness. and thinking agility due to the lack of oxygen support to muscle cell and in the other hand. It may also decrease learning achievement and work productivity (Kementrian Kesehatan Indonesia, 2016). Female adolescents are prone to anaemia. the existence of monthly menstruation cycle is one of the causal factors of female adolescents to be infected by anaemia even it was supported by their fine understanding over anaemia (Mularsih, 2017)
The number of anaemia cases for adolescents in 2011 stood at $11.7 \%$ and $6.7 \%$ of these anaemia evidences occurred during the period of menstruation (Dinas Kesehatan Jawa Timur, 2011). The Regional Office of Public Health of Tuba district had administered during the last 5 years that there has been 69 cases for maternal death (Dinas Kesehatan Kabupaten Tuban. 2016). The symptom of maternal death cane be generated from a number of diseases which may worsen maternal condition before and after giving birth. One of the symptoms of maternal death is intensive bleeding during childbirth due to the mother during her adolescence experienced prolonged. unhandled. and sustained anaemia until her childbirth moment. This issue has been proven to the population of boarding school when the researcher was undertaking preliminary data collection on 18 March 2018 in Boarding School of X. Tuban it was identified that 8 out of 10 female 
students experienced the symptoms of anaemia in times of menstruation. The complained over headache. body weakening. lethargic and weary over their bodies. Another few numbers were also complained to be sleepy in times of performing regular activities at school.

The importance of countermeasure program against anaemia towards female adolescents is for the female adolescents to be physically prepared before pregnancy in order to be fit to become a healthy mother. and during their pregnancy are immune to anaemia. Therefore, it is necessary to perform the research regarding the effort to prevent anaemia for female adolescents based on the level of understanding over anaemia, attitude, and friends support, and health efforts in the effort of preventing anaemia to infect female adolescents in Islamic boarding school.

The purpose of this study was to explain the factors related to the effort of anemia prevention during menstruation on female adolescents in Islamic boarding school.

\section{MATERIALS AND METHODS}

The research was cross sectional design, population were female adolescents studying in 3 different boarding schools that chose randomly in Tuban in July 2018. Total sample obtained 214 respondents by random sampling. Independent variables were knowledge, attitude, friends support, health facility, health efforts, and dependent variables are the effort of anaemia prevention. To pretend bias we used inclusion criteria including adolescents aged between 11-20 years old and had experienced menstruation.

Data is generated through questionnaire arranged by Puspah (2017). Knowledge questionnaire consists of 10 questions with score of 0 to 2. Category: favourable knowledge (76-100\%), adequate knowledge (56-76\%), and deficient knowledge ( $\leq 55 \%$ ), and obtained chronbach alfa 0.893. Attitude questionnaire consists of 16 questions with score between 0-5 and minimum score to be achieved was 0 and maximum score was 80 . Category: possitive $(\geq 62.5 \%)$ negative $(<62.5 \%)$ and obtained chronbach alfa 0.939 .

Friends support questionnaire consists of 7 questions with optional answer of 0 to 4 with maximum score of 28 and minimum score of 0 . Category: Favourable support (76-100\%), adequate support $(56-76 \%)$, deficient support $(\leq 55 \%)$, and obtained chronbach alfa 0.811. Health facility questionnaire consists of 5 questions with optional answer of 0 to 2 . the maximum score was 10 and the minimum score was 0 . The category: favourable (76$100 \%)$. adequate $(56-75 \%)$. deficient $(\leq 55 \%)$ and obtained chronbach alfa 0.783 .

Health efforts questionnaire consists of 6 questions with range answers are 0 until 4 . the maximum score is 0 and the minimum score was 24 . Category: favourable (76-100\%), adequate (56-75\%), deficient $(\leq 55 \%)$, and obtained chronbach alfa 0.779 .
The questionnaire of effort to prevent anaemia consists of 6 questions with optional answers from 0 to 4 , the maximum score was 24 and the minimum score was 0 . The category: favourable (76-100\%). adequate $(56-75 \%)$. deficient $(\leq 55 \%)$ and obtained chronbach alfa 0.783 .

The data analyzed by using Spearman Rho with level of significance $\alpha<0.005$. This research has been declared to have passed the ethical review and obtained an Ethical Approval certificate with No. 992 - KEPK issued by the Nursing Faculty of Airlangga University.

\section{RESULTS}

Table 1 shows that during these ages' respondents were situated in all levels of adolescences but can be discovered more in the middle level of adolescence that is between $15-17$ years old amounting to $48.6 \%$. Early adolescents (11-14 years old) in the amount of 76 respondents or $35.5 \%$ and late adolescents (18-20 years old) amounting to 34 or $15.8 \%$. The majority of respondents encountered menstruation for the first time in the age of 9-12 years old in amount of 144 respondents or equivalent to $67.3 \%$ and those with the first menstruation in the age of 13 years onwards is around 70 respondents or $32.7 \%$ and half of the respondents are studying in high school level that is as much as 107 respondents (50\%).

The result of this analysis shows the existence of connection between knowledge with the effort of anaemia prevention during menstruation $(\mathrm{p}=0.000$; $\mathrm{r}=0.318$ ). It can be inferred that the occurred relationship is weak. The particular analytical result unveils the existence of connection between attitude and the effort of anaemia prevention during menstruation with weak relationship $(\mathrm{p}=0.001$; $r=0.232$ ). The friends support also correlate with the effort of anaemia prevention during menstruation $(p=0.003 ; r=0.203)$. The relationship between health facility with the effort of anaemia during menstruation obtained a weak relationship $(p=0.000$ and $r=0.260$ ), and the relationship there is a weak correlation between health-based undertaking with the effort of anaemia prevention during menstruation $(\mathrm{p}=0.001 ; \mathrm{r}=0.227)$.

\section{DISCUSSION}

\section{Knowledge}

The relationship between knowledge with the effort of anaemia prevention in times of menstruation. From the aforementioned illustration. it can be inferred that the result is a weak result. This is shown by a favourable percentage over knowledge that is closely equivalent. Frequency distribution of knowledge and the effort of anaemia prevention with the largest percentage can be found in the categories of favourable and deficient. This is influenced by the educational background of respondents who in majority are sitting in high school due to an existing probability that these students obtained the 
information regarding anaemia through the subject of science. although living in boarding school. female adolescents are also obtaining the similar general education with those who are not living in boarding school. Education is a prominent factor for those who pay critical attention to preserve their health. However, every of which will be ended up in vain should the intention is not accompanied with awareness and willingness to commence change in their undertakings (Makhfudli, Rachmawati, and Andini, 2017).

The relationship between knowledge and anaemia prevention effort for female adolescents illustrates that female adolescents with minimum knowledge over anaemia leads themselves to the lack of selfawareness to initiate the effort of anaemia prevention. The result if this research is in line with the research carried out by (Mularsih, 2017) whereby respondents with favourable knowledge over anaemia tends to behave supportive to the prevention of anaemia in times of menstruation. in contrary. the respondents with deficient knowledge over anaemia were unlikely to behave supportive in the effort of anaemia prevention in times of menstruation. The other supportive research was carried out by (Puspah, 2017) regarding the factors connected to the prevention of anaemia towards female adolescents in accordance with Lawrence Green theory in SMPN Banjarbaru, Banjarbaru City. South Kalimantan. which shows the existence of relationship between knowledge and anaemia prevention.

Knowledge is determined by education. information from mass media. socio-culture. family support. environment. and age. According to (Leineger, 2002), background of education is influential to the absorbance of information, a person who possess high level of education will also be equipped with a favourable knowledge. Knowledge without favourable education will allow an individual to commit unfavourable decision.

\section{Attitude}

Respondents have positive attitude over the prevention of anaemia. those are amounting to 24 respondents $(11.2 \%)$. in the other hand. respondents with negative attitude are entirely have deficient effort of anaemia prevention in amount of (17.8\%). This finding implies that the better the attitude of respondents. it may increase the effort of anaemia prevention in times of menstruation. Therefore, it can be concluded that there is a relationship between attitude and the effort of anaemia prevention in times of menstruation for female adolescents in Boarding schools within the area of Jen, Tuba District. This research is linier with the research carried out by (Caturiyaningtyas, 2015) regarding the relation between knowledge. attitude. and behaviour with the case of anaemia towards female adolescents in grade X and XI of State Senior High School 1 Polokarto which mentioned that there is a relationship between attitude and the case of anaemia within female adolescents in grade X and XI State Senior High School 1 Polokarto. The research of (Panyuluh and Nugraha, 2018) mentioned that there is no significant relationship between attitude and anaemia prevention within female adolescents in Darul Ulum Islamic Boarding School, Kendal District.

According to Notoatmojo (2012) attitude is not yet to be determined as a form of action or activity. However, it was a pre-disposition of actions towards a certain behaviour. The attitude of an individual is in line with the level of knowledge they previously attained. Positive attitude shapes positive behaviour. and vice versa. This matter is linier with Sarwono on Ningrum (2011), that the change of attitude within an individual start with identification step and later on become internalization. Female students with favourable behaviour towards the effort of anaemia prevention own empathy towards the anaemia prevention in times of menstruation.

\section{Friends support}

The amount of respondent with the friends support is deficient (69.63) or a number of 149 respondents are in adequate category in the effort of anaemia prevention $(31.8 \%)$ and the category of deficient in the effort of anaemia prevention in times of menstruation (33.2), this shows that female adolescents with deficient support from friends with the same age will commence a minimum effort to anaemia prevention primarily in the sense of supports from friends with the same age to obtain iron supplement.

According to Yuswanto (2015) the friends support was a support given for and by a person in similar situation. The similar support consists of an individual who experiences the same challenges with a medical patient who suffer certain infection. certain community. and individuals with similar problems. Hurlock (1980) and Luthfi (2012) argue that social support from friends with the same age is realized in form of the feeling of shared fate which nurtures the existence of understanding relationship towards each other's problem. advice-giving and sympathy that are not obtainable from parents due the parents contribute in desicion making of an adolescent (Yunitasari, Pradanie, and Susilawati, 2016).

\section{Medium of health}

The relationship established within it is a weak relationship and the relationship among these two variables are single-oriented which means the better the health facility obtained. hence. the better as well the effort of anaemia prevention in times of menstruation towards female adolescents in Islamic boarding school. The relationship between health facility with the effort of anaemia prevention in times of menstruation towards female adolescents in Islamic boarding school. The best value is discovered in the statement which unveils that in Islamic boarding school. logistic has provided foods with rich containment of protein and ferrum substance including tofu, soybean, egg, green vegetable in daily 
manner. Meanwhile, the least value can be found in the statement which unveils that in Islamic boarding school there is an absence of blood cell examination tools for female students. The research which against this statement is the research carried out by (Panyuluh and Nugraha, 2018) which mentioned that there is no significant relationship between the availability of health facility towards anaemia prevention for female students of Darul Ulum Islamic Boarding School, Kendal District.

\section{Health supports}

The relationship established within it is a weak relationship and the relationship among these two variables are single-oriented which means the better the health efforts committed. hence. the better as well the effort of anaemia prevention in times of menstruation towards female adolescents in Islamic boarding school.

Almost half of the respondents have deficient health efforts (67.29\%) from the number of respondents who have uncertain health efforts in the number of 144 . There are 73 respondents who are identified with deficient health efforts. This explanation shows that the less the health-relating undertaking committed. the less as well the effort of anaemia prevention in times of menstruation within adolescents in Islamic boarding school. The existence of relationship between health efforts with the effort of anaemia prevention shows the female adolescents with lack of action in responding to health issues are also lack in undertaking prevention effort to anaemia primarily in the case of stockpiling iron supplement.

\section{CONCLUSION}

The factors that are influential towards the effort of anaemia prevention in times of menstruation for female adolescents in Islamic boarding school are knowledge. attitude. friends support. health facility. and health efforts. From the aforementioned factors. the most influential factor is the knowledge of female students over the effort of anaemia prevention.

It is expected that Islamic boarding school as a stakeholder seeks to preserve the availability of healthy and nutritious food as well as for health entities to be able to intensify promotional and preventive events over the importance of anaemia prevention towards adolescents in times of menstruation.

\section{REFERENCES}

A. Goudarzi, M. . M. and K. G. (2008) 'The Effect of Iron Deficiency Anemia on intelligence Quotient (IQ) in under Years Old Students'. Pakistan Journal of Biologi Sciences, 15;11(10): 398-400

Achmad Djaeni Soediaoetomo (2008) Ilmu Gizi Untuk Mahasiswa dan Profesi. Jakarta: Dian Rakyat.

Alvarez-uria, G. et al. (2014) 'Prevalence and Severity of Anaemia Stratified by Age and Gender in Rural India', 2014, pp. 1-6. doi:10.1155/2014/176182
Anwar, M., Baziad, A., \& Prabowo, R. . (2011) Ilmu Kandungan. Jakarta: Bina Pustaka Sarwono Prawirohardjo.

Astuti, R. and Rosidi, A. (2015) 'Faktor Resiko Anemia Pada Siswi Pondok Pesantren', Prosiding Seminar Nasional, (Who 2001), pp. 247-253.

Batubara JRL (2010) 'Sari Pediatri', in Departemen Ilmu Kesehatan Anak FKUI/RSCM. Jakarta.

Chandyo, R. K. et al. (2007) 'Prevalence of iron deficiency and anemia among healthy women of reproductive age in Bhaktapur, Nepal', pp. 262269. doi: 10.1038/sj.ejcn.1602508.

Citrakesumasari (2012) Anemia Gizi Masalah dan Pencegahanna. Yogyakarta: Kalika.

Departemen Agama RI (2000) Pola Perkembangan Pondok Pesantren. Jakarta: Depag RI.

Departemen Kesehatan (2011) 'Kajian Profil Penduduk Remaja di Indonesia'.

Depkes RI (2007) 'Kesehatan, Pedoman Pelenggaraan dan Pembinaan Pos Kesehatan Pesantren', in. Jakarta: Departemen Kesehatan RI Direktorat Jendral Bina Kesehatan Masyarakat.

Dhenok Citra Penyuluh, Priyadi Nugraha P, E. R. (2018) 'Faktor-Faktor yang Behubungan dengan Perilaku Penyebab Anemia pada Santri wati Pondok Pesantren Darul Ulum Kabupaten Kendal', Jurnal Kesehatan Masyarakat, 6(April), pp. 156162. doi: ISSN:2356-3346.

Dinas Kesehatan Jawa Timur (2011) 'Data Laporan Gizi'.

Handayani, W. dan A. S. H. (2008) Asuhan Keperawatan Pada Klien dengan Gangguan Sistem Hematologi. Jakarta: Salemba Medika.

Puspah Hairun (2017), faktor-faktor yang berhubungan dengan upaya pencegahan anemia pada remaja putri berbasis teori Lawrence Green di SMPN 3 Banjarbarukota Banjarbaru Kalimantan Selatan.

Hapzah, R. Y. (2012) 'Hubungan Tingkat Pengetahuan dan Status Gizi Terhadap Kejadian Anemia Remaja Putri Pada Siswi Kelas III Di SMAN Tinambung Kabupaten Polewali Mandar', Media Gizi Pangan, XIII. doi: 10.16182/j.cnki.joss.2007.21.002

John W. Santrock (2007) 'Perkembangan Anak', in. Jakarta: PT. Erlangga.

Kementrian Kesehatan Indonesia (2016) Pedoman Pencegahan dan Penanggulangan Anemia Pada Remaja Putri Dan Wanita Usia Subur (WUS). Jakarta.

Leininger, M., 2002. Culture Care Theory: A Major Contribution to Advance Transcultural Nursing Knowledge and Practices. Journal of Transcultural Nursing, 13(3), pp.189-192. doi: 10.1177/10459602013003005

Makhfudli, Rachmawati, P. and Andini, S. (2017) 'Factors Related to Open Defecation Behavior Among School-Age Children in West Lombok', Jurnal Ners, 12(Leininger 2002), pp. 119-125. doi: 10.20473/jn.v12i1.4028

Manuaba, I. B. G. (2009) 'Memahami kesehatan reproduksi wanita', in. Jakarta: EGC. 


\section{E. YUNITASARI ET AL.}

Manuaba, I. G. B. (2006) Buku Ajar Patalogi Obstetri Untuk Mahasiswa Kebidanan (Cetakan I). Jakarta: Penerbit Buku Kedokteran EGC.

Masrizal (2007) 'Studi Literatur Anmeia Defisiensi Besi', Kesehatan Masyarakat.

Masuthu (2014) Dinamika Sistem Pendidikan Pesantren. Jakarta: Indonesia Corporation in Islamic Studies.

Nicki L. Potts \& Barbara L. Mandleco (2007) 'Pediatric Nursing Caring for Children and Theis Families Second Edition'.

Nizomy, R. (2002) 'Mekanisme Fisiologi Perdarahan Haid', in Jurnal Berkala Kedokteran Vol 2. MeiAgustu. Jakarta.

Nur Ia Kaimudin, Hariati Lestari, J. R. A. (2017) 'Skrining dan Determinan Kejadian Anemia pada Remaja Putri SMA Negeri 3 Kendari Tahun 2017', Jurnal Ilmiah Mahasiswa Kesehatan Masyarakat, 2(6), pp. 1-10.

Nursalam (2016) 'Metodologi Penelitian Ilmu Keperawatan: Pendekatan Praktis', in. Jakarta: Salemba Medika, p. 454.

Prawiroharjo, S. (2011) Ilmu Kandungan. Jakarta: PT Bina Pustaka.

Proverawati, A. (2011) Anemia dan Anemia Kehamilan. Yogyakarta: Nuha Medika.

Puspah Hairun (2017) Faktor-Faktor Yang Berhubungan Dengan Pencegahan Anemia Pada Remaja Putri Berbasis Teori Lawrence Green di SMPN 3 Banjarbaru Kota Banjarbaru Kalimantan Selatan.

Raindi, A. B. (2011) Pola Pembinaan Pesantren Daar Al-Taubah terhadap Akhlak Mulia Wanita Tuna Susila. Repository UPI.

Sri, Y. (2013) Laporan Kegiatan Pelayanan Kesehatan Masyarakat Primer (PMKP) dan Usaha Kesehatan Masyarakat. Wonosobo: Puskesmas Mojotengah.

Sri Mularsih (2017) 'Hubungan Pengetahuan Remaja
Putri Tentang Anemia Dengan Perilaku Pencegahan Anemia Pada Saat Menstruasi Di Smk Nusa Bhakti Kota Semarang', 6(2), pp. 80-85. doi: 10.26714/jk.6.2.2017.80-85

Titin Caturiyantiningtyas (2015) 'Hubungan Antara Pengetahuan, Sikap Dan Perilaku Dengan Kejadian Anemia Remaja Putri Kelas X Dan Xi Sma Negeri 1 Polokarto'.

Tarwoto dkk (2010) Kesehatan Remaja Problem dan Solusinya. Jakarta: Salemba Medika.

Tarwoto Dkk (2010) Kesehatan Remaja Problem dan Solusinya. Jakarta: Salemba Medika.

Temi Chintia Risva, Suyatno, M. Z. R. (2016) 'FaktorFaktor yang Berhubungan dengan Kebiasaan Konsumsi Tablet Tambah Darah Sebagai Upaya Pencegahan Anemia Pada Remaja Putri (Studi pada Mahasiswa Tahun Pertama di Fakultas Kesehatan Masyarakat Universitas Diponegoro', 4(April), pp. 243-250.

Dinas Kesehatan Tuban, (2016) 'Profil Kesehatan Kabupaten Tuban Tahun 2016'.

Wong, D.l, Hockenberry, M, et al. (2009) Buku Ajar Keperawatan Pediatri. 6th edn. Jakarta: EGC.

World Health Organization (2011) 'Haemoglobin Concentrations for The Diagnosis of Anaemia and Assessment of Severity'.

World Health Organization, Stoltzfus, R. J. and Dreyfuss, M. L. (2013) 'Prevention of Iron Deficiency Anaemia in Adolescents Role of Weekly Iron Acid Supplementation', Pediatrics, 138(1), p. 46. doi: 10.3390/nu6125915.

Yunitasari, E., Pradanie, R. and Susilawati, A. (2016) Kecamatan Torjun Sampang Madura (Early Marriage Based on Transcultural Nursing Theory in Kara Village Sampang)', Jurnal Ners, 11(2015),pp. 164-169. doi: 10.20473/jn.V11I22016.164-169. 